\title{
Responses of Horticultural Commodities to High Carbon Dioxide as Related to Modified Atmosphere Packaging
}

\author{
Christopher B. Watkins
}

\begin{abstract}
ADDITIONAL INDEX WORDS. postharvest, storage, modified atmosphere packaging, minimal processing
Summary. The tolerances of horticultural commodities to $\mathrm{CO}_{2}$ are outlined, as are also the associated biochemical and physiological aspects of differences in tolerance between and within commodity types. These tolerances are related to responses to the use of modified atmosphere packaging (M AP) during storage. Commodities vary widely in their responses to elevated $\mathrm{CO}_{2}$, and low tolerance to the gas limits its use to maintain quality in some cases. Standard recommendations are generally those established to extend the storage period of any given commodity as long as possible, and safe atmospheres may differ substantially for shorter term exposures used in M AP. U se of MAP for storage of minimally processed products represents an important example of this, as storage periods and quality attributes required for commercial marketing of cut products can be very different from those of the whole product. Factors such as cultivar and postharvest treatment before imposing high $\mathrm{CO}_{2}$ can influence responses of commodities to $\mathrm{CO}_{2}$, but are rarely considered in cultivar selection or in commercial application. A better understanding of the physiology and biochemistry of commodity responses to $\mathrm{CO}_{2}$ is required for increased use of M AP.
\end{abstract}

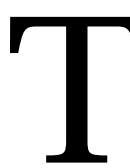

he focus of this paper is on $\mathrm{CO}_{2}$ effects as they pertain to modified atmosphere packaging. In an associated paper, Beaudry (2000) has described factors associated with responses of horticultural commodities to low $\mathrm{O}_{2}$, but under M AP conditions elevated $\mathrm{CO}_{2}$ is also a major factor influencing quality of fruit and vegetables. Indeed, it is often the elevated $\mathrm{CO}_{2}$ in addition to, or rather than, the low $\mathrm{O}_{2}$ that exerts beneficial or detrimental effects.

The posthar vest tolerances of most commercially important fruit and vegetables to high $\mathrm{CO}_{2}$ concentrations have been established, the general goal being to identify the safe concentrations (in conjunction with the accompanying $\mathrm{O}_{2}$ concentration) that will result in maximum commodity storage life without injury. When a fruit or vegetable is subjected to atmospheres outside safe limits at any temperature/ time combination, damage may be manifested as irregular ripening, initiation and/ or aggravation of certain physiological disorders, development of off-flavors, and increased susceptibility to decay. 
Tolerances of commodities to high $\mathrm{CO}_{2}$ levels are affected by both metabolic and physical factors. Responses of horticultural commodities to $\mathrm{CO}_{2}$ can vary dramatically among species, cultivars and strains, organ types, and developmental stages, and can be either unwanted or highly desirable, depending on the product. Generally it is assumed that $\mathrm{CO}_{2}$ directly affectsrespiration and associated metabolic pathways, as well as pathways involved in secondary metabolism such as production of ethylene, pigments, phenolics, and volatiles (Beaudry, 1999; Kader, 1997a). H owever, physical effects such as skin thickness that influence gas exchange will affect gaseous equilibrium between the outside and inside of the tissue and thereby influence the susceptibility of products to injury (Burton, 1974). Therefore, the recommended storage atmospheres represent ones that are safefor the overall po pulation of intact fruit or vegetables rather than for individuals, whose physiology can vary greatly.

The objectives of this presentation are to outline the tolerances of horticultural commodities to $\mathrm{CO}_{2}$, to describetheassociated biochemical and physiological aspects of differences in tolerance between and within commodity types, and to focus on how these variables relate to the use of M AP during storage. The fungistatic effects of $\mathrm{CO}_{2}$ on decay incidence in M AP (D eV ries-Paterson et al., 1991) are not considered here.

\section{Tolerances of horticultural commodities to carbon \\ dioxide}

Sources of information for recommended $\mathrm{CO}_{2}$ ( and $\mathrm{O}_{2}$ ) concentrations for most horticultural commodities include Beaudry (1999), Kader (1997a), referencescited by Kader and Watkins (2000), and the Proceedings from the I nternational Controlled Atmosphere Conferences held every 4 years (e.g., Gorny, 1997; Kader, 1997b; Kupferman, 1997; Saltveit, 1997).

These recommendations generally represent the conditions that will result in maximum storage life of each commodity. H owever, it is also useful to examine the differences in tolerancesto $\mathrm{CO}_{2}$ among commodities. An extremely wide range of $\mathrm{CO}_{2}$ concen- trations beyond which injury occurs existsfor different commodities(T able $1)$. Whereas $2 \% \mathrm{CO}_{2}$ represents the upper level for lettuce, some berryfruit, figsand cherimoya can tolerate $25 \%$ or higher. It should be noted that these limits have been identified by storing commodities for maximum periods, and therefore may be lower than those that are safe for short-term storage. $U$ nderstanding the reasons for differences in susceptibility to $\mathrm{CO}_{2}$ injury may yield information that can beused to expand uses of M AP and other uses of $\mathrm{CO}_{2}$ such as disinfestation treatments and decay control.

\section{Effects of $\mathrm{CO}_{2}$ on metabolism}

At the metabolic level, more information exists for effects of $\mathrm{O}_{2}$ than for $\mathrm{CO}_{2}$ because of the extensive research that has been carried out on anoxia and hypoxia in many different plant materials (Ratcliffe, 1995). In contrast, information about the effects of high $\mathrm{CO}_{2}$ is largely limited to fruit and vegetables after harvest. $O$ verall, there are many similarities between the effects of low $\mathrm{O}_{2}$ and high $\mathrm{CO}_{2}$ on metabolism, with most effects being suppression of various metabolic processes (Beaudry, 1999; Kader, 1997a). The following exceptions are evident.

- Respiration is usually inhibited by low $\mathrm{O}_{2}$, but can be inhibited, unaffected or stimulated by high $\mathrm{CO}_{2}$ in the storage environment (M athooko, 1996a). The stimulation of respiration may represent stress responses by the tissue.

- 1-Aminocyclopropane-1-carboxylic acid (ACC) synthase activity is inhibited by both low $\mathrm{O}_{2}$ and high $\mathrm{CO}_{2}$. $\mathrm{H}$ owever, while ACC oxidase activity is inhibited by low $\mathrm{O}_{2}$, it is stimulated and inhibited by low and high $\mathrm{CO}_{2}$ concentrations, respectively (M athooko, 1996b).

- Activity of phenylalanine ammonia lyase (PAL), an enzyme involved in phenolic metabolism, is inhibited by low $\mathrm{O}_{2}$ but is enhanced by high $\mathrm{CO}_{2}$ in some (Prusky et al., 1996), but not all, tissues (H olcroft et al., 1998).

- $\mathrm{H}$ igh $\mathrm{CO}_{2}$ is a competitiveinhibitor of ethylene action (Burg and Burg, 1967).

Research on high $\mathrm{CO}_{2}$ effects on metabolism has focused on the primary metabolic pathways, such as glycolysis, fermentation, TCA cycle, and the mitochondrial respiratory chain. A complete cataloging of the effects of high $\mathrm{CO}_{2}$ on individual enzymes will not be provided here, but rather, broad statements and identifications of differences between theaction of low $\mathrm{O}_{2}$ and high $\mathrm{CO}_{2}$ will be made. $\mathrm{H}_{\text {igh }} \mathrm{CO}_{2}$ appears to do the following.

- Increase carbon flux through glycolysisand maintain energy levelsin the cell. Activation of glycolysismay not involve the same enzymes as those affected by low $\mathrm{O}_{2}$, especially thephosphofructokinases, PPi-PFK and ATP-PFK (Kerbel et al., 1990). Also, pyruvate kinase and pyruvate decarboxylase activities are affected differently by low $\mathrm{O}_{2}$ and high $\mathrm{CO}_{2}$ (Silva, 1998).

- Increase carbon flux through the fermentation pathway, although activation of pyruvate decarboxylase (PDC) and alcohol dehydrogenase $(A D H)$ is less evident in high $\mathrm{CO}_{2}$ than in low $\mathrm{O}_{2}$ treatments ( $\mathrm{Ke}$ et al., 1995).

- Result in accumulation of the TCA cycle intermediate, succinate, in $\mathrm{CO}_{2}$, but not in $\mathrm{O}_{2}$-treated tissues. Thisaccumulation, which isthought to be toxic to plant cells (H ulme, 1956), may be related to theinhibition of succinate dehydrogenase (SDH) activity (Frenkel and Patterson, 1973; Ke et al., 1993). Succinate accumulation could also result, however, from activation of the glyoxylate cycle (Yang et al., 1998), the $\gamma$-aminobutyrate shunt (Satya N arayan and Nair, 1986), and/ or phosphoenolpyruvate carboxylaseactivity (Bisbiset al., 1997).

- Enhance the alternative pathway by induction and/ or activation of the alternative oxidase, and inhibition of the cytochrome pathway by suppression of cytochrome oxidase activity, although treatment effects can be diverse according to physiological state of the tissue, harvest season, temperature, and $\mathrm{CO}_{2}$ concentration ( $\mathrm{L}$ ange and $\mathrm{K}$ ader, 1997a).

Both $\mathrm{CO}_{2}$ and $\mathrm{O}_{2}$ may affect enzyme activities by changing therates of degradation and/ or synthesis, activation and/ or inactivation, substrateand cofactor availability, or a combination of these processes. In addition, $\mathrm{CO}_{2}$ may cause complex interactions in tissues, including changes in the kinetics of allosteric proteins (M itz, 1979). 


\begin{tabular}{|c|c|}
\hline $\mathrm{CO}_{2}(\%)$ & Commodity \\
\hline 2 & L ettuce (crisphead) (Lactuca sativa L.) \\
\hline \multirow[t]{2}{*}{3} & Artichoke (Cynara scolymus L.) \\
\hline & Tomato [Lycopersicon esculentum (L.) M ill.] \\
\hline \multirow[t]{6}{*}{5} & Apple (most cultivars) (M alusxdomestica Borkh.] \\
\hline & Cauliflower (Brassica oleracea L. G roup Botrytis) \\
\hline & Cucumber (CucumissativusL.) \\
\hline & Grape (Vitisvinifera L.) \\
\hline & N ashi (Pyrusserotina Rehd.) \\
\hline & Olive (Olea europaea L.) \\
\hline \multirow[t]{3}{*}{7} & Banana (Musa sp.) \\
\hline & Bean (green snap) (Phaseolus vulgarisL.) \\
\hline & Kiwifruit [A ctinidia deliciosa (A. Chev) C.F. Liang et A.R. Ferguson var. deliciosa] \\
\hline 8 & Papaya (Carica papaya L.) \\
\hline \multirow[t]{7}{*}{10} & Asparagus (A sparagus officinalisL.) \\
\hline & Brussels sprouts (Brassica oleracea L. Group Gemmifera) \\
\hline & Cabbage (Brassica oleracea L. G roup C apitata) \\
\hline & Celery [A pium graveolens L. dulce (M ill.) Pers. ] \\
\hline & Grapefruit (C itrusparadis M acf.) \\
\hline & Lemon (Citrusjambhiri Lush.) \\
\hline & Lime (Citruslimettioides Tan) \\
\hline & Broccoli (Brassica oleracea L. Group I talica) \\
\hline & Lychee (Litchi chinensis Sonn.) \\
\hline & Plum (Prunus×domestica L.) \\
\hline & Pomegranate (Punica granatum L.) \\
\hline & Spinach (Spinacia oleracea L.) \\
\hline & Sweetsop (A nnona squamosa L.) \\
\hline \multirow[t]{4}{*}{20} & Cantaloupe (muskmelon) (C ucumismelo L.) \\
\hline & Durian (D urio zi bethi nus M urr.) \\
\hline & M ushroom (A garicusbisporusL.) \\
\hline & Rambutan (N ephelium lappaceum L.) \\
\hline \multirow[t]{5}{*}{25} & Blackberry (R ubusL. subg. R ubus Watson) \\
\hline & Blueberry (Vaccinium corymbosum L.) \\
\hline & Fig (Ficuscarica L.) \\
\hline & Raspberry (R ubusidaeusL.) \\
\hline & Strawberry (Fragaria ×ananassa D uch.) \\
\hline 30 & Cherimoya (A nnona cherimola M ill.) \\
\hline
\end{tabular}

Enzyme activities may also be affected by acidification of the cytoplasm by $\mathrm{O}_{2}$ and $\mathrm{CO}_{2}$. $\mathrm{O}$ xygen effects may be associated with stimulation of lactic dehydrogenase, while those of $\mathrm{CO}_{2}$ are usually ascribed to the generation of carbonic acid and subsequent lowering of the intracellular $\mathrm{pH}$ (Burton, 1974). The pH changes in the cytoplasm could affect the activity of sev- eral key enzymes in situ. Theoretical considerations indicate that acidification will occur at $\mathrm{CO}$ concentrations above $5 \%$ (Bown, 1985). H owever, strong evidence for lowering of $\mathrm{pH}$ in 


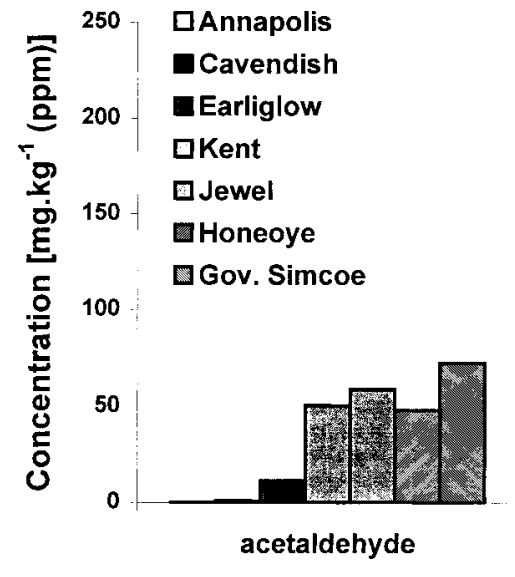

Fig. 1. Acetaldehyde and ethanol concentrations in seven strawberry cultivars when exposed to $20 \mathrm{kPa}$ $\mathrm{CO}_{2}$ for $\mathbf{7 d}$ (modified from Watkins et al., 1999). No detectable acetaldehyde or ethanol were found for 'Annapolis'. D ata are means of three replications per cultivar, and cultivar differences are significant at $\mathbf{P} \leq$ 0.001 .

$\mathrm{CO}_{2}$-treated tissues is not easily obtained, especially in bulky fruit tissues, although Lange and Kader (1997b) found that $20 \%$ to $40 \% \mathrm{CO}_{2}$ decreased the in vivo $\mathrm{pH}$ of avocado. D ecreases in cytoplasmic pH havebeen indicated bynuclear magnetic resonance( N M R) measurements (Siriphanich and Kader, 1986). Indirect evidence for acidiosis has also been obtained by $\gamma$ aminobutyrate accumulation in $\mathrm{CO}_{2}$ treated tissue since it is produced by the decarboxylation of glutamate in a proton-consuming glutamate decarboxylation reaction stimulated by lower cell pH (Ke et al., 1993). H owever, in vivo cellular $\mathrm{pH}$ may remain fairly constant because of buffering capacity; this capacity may vary among tissue types and the overall importance of acidification in tissueresponses to high $\mathrm{CO}_{2}$ is not yet certain.

\section{Factors affecting tolerances of horticultural commodities to $\mathrm{CO}_{2}$}

Cultivar. Cultivar effects on susceptibility of commodities to $\mathrm{CO}_{2}$ injury have been noted, e.g. in lettuce (Lopez-Galvez et al., 1996) and in apples (Wilkinson and Fidler, 1973). These have rarely been used to investigate the mechanisms of $\mathrm{CO}_{2}$ action, although $\mathrm{Ke}$ et al. (1993) found no differences in metabolism of organic and amino acids in cultivars of crisphead lettuce with varying tolerances to thegas. Recently, we have identified two groups of strawberrycultivars that vary widely in their re sponses to elevated $\mathrm{CO}_{2}$ asindicated by accumulation of the fermentation products, acetaldehydeand ethanol (Fig. 1) ethanol to $\mathrm{CO}_{2}$ tolerance under MAP conditions have been revealed by the occurrence of $\mathrm{CO}_{2}$-related disorders during controlled atmosphere storage in a number of new commercial apple cultivars such as 'B raeburn', 'E mpire' and 'Fuji'. Storage losses from these disorders have stimulated research that illustrates several important features of $\mathrm{CO}_{2}$ tolerance. Susceptibility of apples to $\mathrm{CO}_{2}$ injury is affected by the following.

- The timing of exposure of fruit to elevated $\mathrm{CO}_{2}$ during $\mathrm{CA}$ storage. A pples are more susceptible to $\mathrm{CO}_{2}$ injury during the first several weeks of CA storage. When 'Empire' apples are exposed to $5 \% \mathrm{CO}_{2}$ for 4 week intervals during normal $\mathrm{CA}$ storage conditions of $2 \% \mathrm{CO}_{2}$ and $2 \% \mathrm{O}_{2}$, most injury occurs during the first 4 weeks (Watkins et al. 1997). Elgar et al. (1998) found similar results for 'B raeburn'.

- Storage time in air before exposure to elevated $\mathrm{CO}_{2}$. If 'Empire', 'Braeburn' or 'B ramley's Seedling' apples are kept in air storage for as little as 4 to $5 \mathrm{~d}$ before exposure to elevated $\mathrm{CO}_{2}$, susceptibility to injury declines markedly (Fig. 2) (Colgan et al., 1999; Elgar et al., 1998; Watkins et al., 1997).

- Postharvest treatment with the antioxidant diphenylamine (DPA). DPA, which is widely used as a postharvest drench to prevent a physiological disorder known as superficial scald, can prevent $\mathrm{CO}_{2}$ induced injury (Fig. 2) (Burmeister and Dilley, 1995; Watkins et al. 1997).

Theimplication of these studies is that in addition to cultivar effects, storage conditions, delays before application of MAP, and/ or postharvest chemical treatment can affect tolerance of horticultural products to $\mathrm{CO}_{2}$. Therefore, research on M AP of apples, for example, carried out with freshly harvested or stored fruit, with or without DPA treatment could result in different conclusions being reached for either fresh or minimally processed products.

\section{Effects of minimal processing}

A rapid increase in marketing of minimally processed products has led to a concomitant increase in application of MAP technologies (Gorny, 1997). M inimal processing can have 


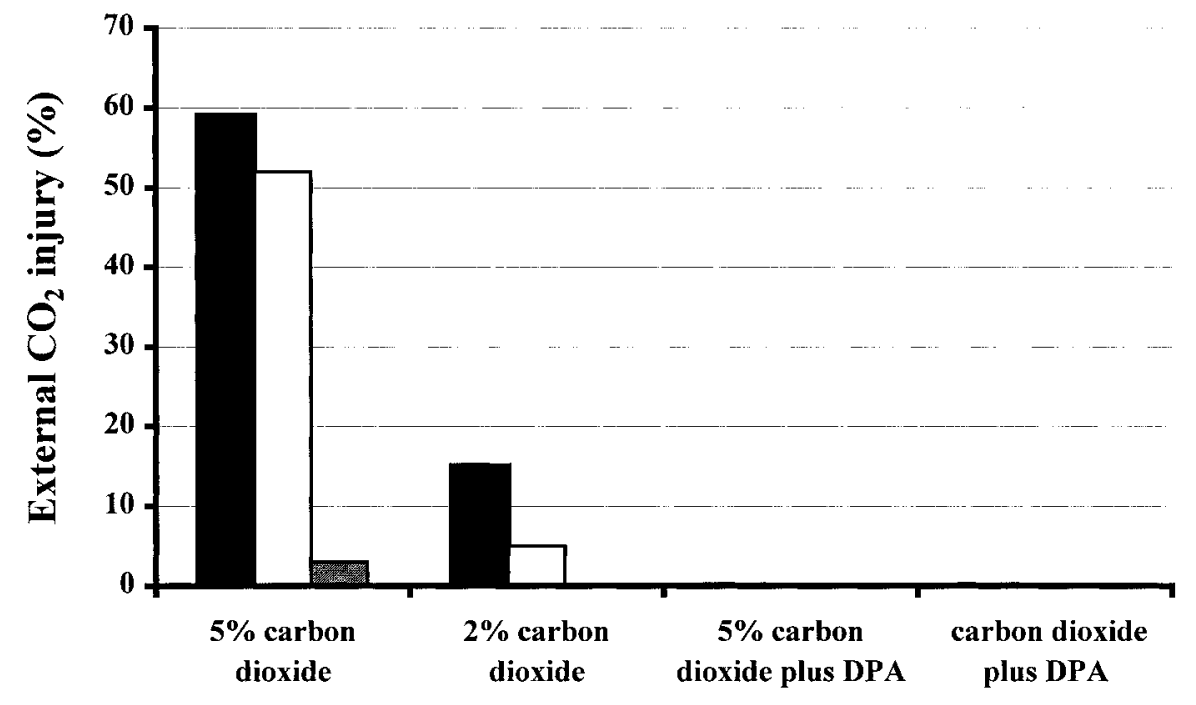

Treatment

Fig. 2. External $\mathrm{CO}_{2}$ injury of 'E mpire' apple fruit, treated with either water or $5.9 \mathrm{~mm}$ diphenylamine (DPA) at harvest, and placed in air storage [ $2.2^{\circ} \mathrm{C}$ ( $36^{\circ} \mathrm{F}$ )] for $1 d$ (black bars), $4 \mathrm{~d}$ (white bars) or $7 \mathrm{~d}$ (grey bars) before being exposed to $2 \%$ or $5 \% \mathrm{CO}_{2}$ (in $2 \% \mathrm{O}_{2}$ ) for 20 weeks. D ata are provided for two combined orchard lots of fruit (modified from Watkins et al., 1997).

very direct effects on the tolerances of products to $\mathrm{CO}_{2}$ by disrupting physical barriers between the external and internal environments, and removing

Table 2. Comparisons of $\mathrm{CO}_{2}$ tolerance for selected whole and fresh cut fruits and vegetables. (M odified from G orny (1997), H erner (1987), Kader (1997b), Kader et al. (1989), and Saltveit (1997)).

\begin{tabular}{lrc}
\hline & \multicolumn{2}{c}{$\begin{array}{c}\mathrm{CO}_{2} \text { concn (\%) } \\
\text { beyond which } \\
\text { injury occurs }\end{array}$} \\
\cline { 2 - 3 } Commodity & Whole & Fresh cut \\
\hline Broccoli & 15 & 9 \\
Cabbage & 10 & 20 \\
Cantal oupe & 20 & 20 \\
Carrot & 5 & 20 \\
Kiwifruit & 7 & 10 \\
Lettuce & 2 & 10 \\
M ushroom & 20 & 20 \\
O nion & 1 & 15 \\
Peach & $5-10$ & 12 \\
Pear & 2 & 10 \\
Pepper & 5 & 10 \\
Spinach & 15 & 13 \\
Strawberry & 25 & 12 \\
\hline
\end{tabular}

the primary limitation imposed by skin resistance to gas diffusion. Accordingly, one might expect tolerances to $\mathrm{CO}_{2}$ to differ greatly between whole and minimally processed products. Table 2 shows that $\mathrm{CO}_{2}$ concentrations, beyond which injury symptoms occur on fresh cut products, can be higher than, equal to or lower than that for symptom development on whole products. These differences can occur for at least two important reasons.

- Storage conditions for processed products can differ greatly from those for whole products. Storage periods are typically much shorter for processed products than for whole products. A cut product has greater surface area, and is potentially subject to greater water loss, more damaged sites, higher respiration and ethylene production rates, and higher microbial growth. While M AP can delaythese events (G orny, 1997), the cut product is more metabolically active than the whole product, aswell as being more prone to decay, and therefore shorter lived.

- The attributes of importance to the consumer, and hence the optimum atmosphere for storage to provide these attributes, can be different for each type of product. I n strawberry, higher $\mathrm{CO}_{2}$ concentrations are recommended for whole berries than for slices; $\mathrm{CO}_{2}$ concentrations of $15 \%$ to $20 \%$ that maintain firmness and reduce decay, also result in bleaching of the internal flesh color (Gil et al., 1997). Such bleaching is not a marketing limitation for a whole product but isnot acceptable for slices (Wright and Kader, 1997). I n contrast, for lettuce, higher $\mathrm{CO}_{2}$ concentrations are recommended for minimally processed lettucethan for the whole product. Whole lettuce can be damaged by disorders known as brown stain, and heart leaf injury, and/ or accumulations of fermentation products, at $\mathrm{CO}_{2}$ concentrationsaslow as $2 \%$ ( $M$ ateos et al., 1993a, 1993b). In the processed product, however, elevated $\mathrm{CO}_{2}$ prevents browning associated with the midribs and cut surfaces (L opez-G alvez et al., 1996; M ateos et al., 1993a, 1993b).

In addition, effects of cultivar, such asthosedescribed earlier for wholeproducts, will be important in evaluating responses of cut products. Examples al ready shown include products as diverse as lettuce (Lopez-Galvez et al., 1996) and apple (Kim et al., 1993). Lopez-Galvez et al. (1996) have also investigated effects of storage periods of whole products before processing. To date, however, no attention has been given to thepossible effects of storageor postharvest chemical usage on tolerances of minimally processed products to elevated $\mathrm{CO}_{2}$. D ata presented earlier on effects of D PA and delayed exposure to $\mathrm{CO}_{2}$ on responses of whole apple to the gas suggest that these effects could be substantial.

Commercially, there seems to be little recognition and perhaps even less interest in dealing with variations in product responses related to cultivar or postharvest effects on a day to day basis. A one-size-fits-all process is preferred, but failure to recognize these effects could result in misleading conclusions about efficacy of a process under investigation, or to variable responses to a process after it put into practice.

\section{Literature cited}

Beaudry, R.M. 1999. Effect of $\mathrm{O}_{2}$ and $\mathrm{CO}_{2}$ partial pressure on selected phenomena affecting fruit and vegetablequality. Postharvest Biol. T echnol. 15:293-303.

Beaudry, R.M . 2000. Responses of horticultural commodities to low oxygen: Limits to the expanded useof M AP. H ortT echnology 10(3):491500.

Bisbis, B., C. Kevers, and T. Gaspar. 1997. Atypical TCA cycle and replenishment in nonphotosynthetic fully habituated sugarbeet callus overproducing polyamines. Plant Physiol. Biochem. 35:363-368. 
Bown, A.W. 1985. $\mathrm{CO}_{2}$ and intracellular pH. Plant Cell Environ. 8:459-465.

Burg, S.P. and E.A. Burg. 1967. M olecular requirementsfor the biological activity of ethylene. Plant Physiol. 42:144-152.

Burmeister, D.M. and D.R. Dilley. 1995. A 'scald-like' controlled atmosphere storage disorder of Empire apples-A chilling injury induced by $\mathrm{CO}_{2}$. Postharvest Biol. Technol. 6:1-7.

Burton, W.G. 1974. Some bio-physical principlesunderlying the controlled atmospherestorage of plant material. Ann. Appl. Biol. 78:149168.

Colgan, R.J., C.J. D over, D.S. Johnson, and K. Pearson. 1999. D elayed CA and oxygen at $1 \mathrm{kPa}$ or less control superficial scald without $\mathrm{CO}_{2}$ injury on Bramley's Seedling apples. Postharvest Biol. Technol. 16:223-231.

Corrigan, V.K. and A. Carpenter. 1993. Effects of treatment with elevated carbon dioxide levels on the sensory quality of asparagus. N .Z. J. Crop H ort. Sci. 21:349-357.

D eV ries-Paterson, R.M., A.L. Jones, and A.C. Cameron. 1991. Fungistatic effects of carbon dioxidein a packageenvironment on the decay of $M$ ichigan sweet cherries by M onilinia fructicola. Plant D is. 75:943-946.

Elgar, H .J ., D .M . Burmeister, and C.B. Watkins. 1998. Storage and handling effects on a $\mathrm{CO}_{2}-$ related internal browning disorder of 'Braeburn' apples. H ortScience 33:719-722.

Fernández-Trujillo,J J.P., J.F.N ock, and C.B.Watkins. 1999. Fermentative metabolism and organic acid concentrations in fruit of selected strawberry cultivars with different tolerances to carbon dioxide. J. Amer. Soc. H ort. Sci. 124:696-701.

Frenkel, C. and M .E. Patterson. 1973. Effects of carbon dioxide on activity of succinic dehydrogenase in 'Bartlett' pears during cold storage. $\mathrm{H}$ ortScience 8:395-396.

Gil, M .I ., D .M . H olcroft, and A.A. Kader. 1997. Changes in strawberry anthocyanins and other polyphenols in response to carbon dioxide treatments. J. Agric. Food Chem. 45:1662-1667.

Gorny, J.R. 1997. A summary of CA and MA requirementsand recommendationsfor fresh cut (minimally processed) fruits and vegetables, $\mathrm{p}$. 30-66. In: J. Gorny (ed.). Proc. 7th Intl. Controlled Atmosphere Res. Conf. vol. 5. Fresh-cut fruits and vegetables and MAP. U niv. Calif. Postharvest H ort. Ser. 19.

$\mathrm{H}$ erner, R.C. 1987. High $\mathrm{CO}_{2}$ effects on plant organs, p 239-253. In: J. Weichman (ed.). Postharvest physiology of vegetables. $M$ arcel D ekker, Inc., N ew York.

H olcroft, D.M., M .I. Gil, and A.A. Kader. 1998. Effect of carbon dioxide on anthocyanins, phenylalanineammonialyase and glucosyltransferase in the arils of stored pomegranates. J. Amer. Soc. H ort. Sci. 123:136-140.

H ulme, A.C. 1956. Carbon dioxide injury and presence of succinic acid in apples. $N$ ature 178:218-219.
Kader, A.A. 1997a. Biological bases of $\mathrm{O}_{2}$ and $\mathrm{CO}_{2}$ effects on postharvest life of horticultural perishables, p. 160-163. In: M .E. Saltveit (ed.). Proc. 7th I ntl. Controlled AtmosphereRes. Conf. vol. 4. Vegetables and ornamentals. U niv. Calif. Postharvest H ort. Ser. 18.

Kader, A.A. 1997b. A summary of CA requirementsand recommendationsfor fruitsother than apples and pears, p. 1-36. In: A.A. Kader (ed.). Proc. 7th I ntl. Controlled AtmosphereR es. Conf. vol. 3. Fruits other than apples and pears. U niv. Calif. Postharvest $\mathrm{H}$ ort. Ser. 17.

Kader, A.A. and C.B. Watkins. 2000. M odified atmosphere packaging-Towards 2000 and beyond. H ortT echology 10(3):483-486.

Kader, A.A., D. Zagory, and E.L. Kerbel. 1989 Modified atmosphere packaging of fruits and vegetables. Crit. Rev. Food Sci. N utr. 28:1-30.

Ke, D., M . M ateos, J. Siriphanich, C. Li, and A.A. Kader. 1993. Carbon dioxide action on metabolism of organic and amino acids in crisphead lettuce. Postharvest Biol. Technol. 3:235-247.

Ke, D., E. Yahia, B. H ess, L. Zhou, and A.A. Kader. 1995. Regulation of fermentative metabolism in avocado fruit under oxygen and carbon dioxide stresses. J. Amer. Soc. H ort. Sci. 120:481-490.

Kerbel, E.L., A.A. Kader, and R.J . Romani. 1990. Respiratory and glycolytic response of suspension-cultured 'Passe Crassane' pear fruit cells to elevated $\mathrm{CO}_{2}$ concentrations. J. Amer. Soc. H ort. Sci. 115:111-114.

Kim, D.M., N.L. Smith, and C.Y. Lee. 1993. $Q$ uality of minimally processed apple slices from selected cultivars. J. Food Sci. 58:1115-1117.

Kupferman, E. 1997. Controlled atmosphere storage of apples, p. 1-31. In: E.J. M itcham (ed.). Proc. 7th I ntl. Controlled AtmosphereRes. Conf. vol. 2. Apples and pears. U niv. Calif. Postharvest H ort. Ser. 16.

L ange, D.L. and A.A. Kader. 1997a. Changes in alternative pathway and mitochondrial respiration in avocado in response to elevated carbon dioxide levels. J. Amer. Soc. H ort. Sci. 122:245252.

Lange, D.L. and A.A. Kader. 1997b. Elevated carbon dioxide exposure alters intracellular $\mathrm{pH}$ and energy charge in avocado fruit tissue. J. Amer. Soc. H ort. Sci. 122:253-257.

Lopez-Galvez, G., M. Saltveit, and M . C antwell. 1996. The visual quality of minimally processed lettuces stored in air or controlled atmosphere with emphasis on romaine and iceberg types. Postharvest Biol. Technol. 8:179-190.

Lurie, S. 1992. M odified atmosphere storage of peaches and nectarines to control physiological disorders. J. Food Q uality 16:57-65.

M ateos, M ., D . Ke, M . C antwell, and A.A. Kader 1993a. Phenolic metabolism and ethanolic fermentation of intact and cut lettuce exposed to $\mathrm{CO}_{2}$-enriched atmospheres. Postharvest Biol. Technol. 3:225-233.

M ateos, M ., D. Ke, A.A. Kader, and M . C antwell. 1993b. D ifferential responses of intact and minimally processed lettuce to high carbon dioxide atmosphere. Acta H ort. 343:171-174.

M athooko, F.M. 1996a. Regulation of respiratory metabolism in fruits and vegetables by carbon dioxide. Postharvest Biol. Technol. 7:1-26.

M athooko, F.M . 1996b. Regulation of ethylene biosynthesis in higher plants by carbon dioxide. Postharvest Biol. Technol. 9:247-264.

Mitz, M.A. 1979. CO biodynamics: A new concept of cellular control. J. Theor. Biol. 80:537551.

Prusky, D ., H . H amdan, R. Ardi, and N .T . Keen. 1996. Induction of biosynthesis of epicatechin in avocado suspension cellstreated with an enriched $\mathrm{CO}_{2}$ atmosphere. Physiol. Mol. Plant Pathol. 48:171-178.

Ratcliffe, R.G. 1995. M etabolic aspects of anoxic response in plant tissue, p. 111-127. In: $\mathrm{N}$. Smirnoff (ed.). Environment and plant metabolism: Flexibility and acclimation, Bios Sci., O Xford, England.

Saltveit, M .E. 1997. A summary of CA and M A requirementsand recommendationsfor harvested vegetables, p. 98-117. In: M.E. Saltveit (ed.). Proc. 7th Intl. Controlled Atmosphere Res. Conf. vol. 4. Vegetables and ornamentals. U niv. Calif. Postharvest H ort. Ser. 18.

Satya N arayan, V. and P.M. N air. 1986. The 4aminobutyrateshunt in Solanum tuberosum. Phytochemistry 25:997-1001.

Silva, S. 1998. Regulation of glycolytic metabolism in asparagus spears (A sparagus officinalis L.). PhD thesis. M ich. State U niv., E. L ansing.

Siriphanich, J. and A.A. Kader. 1986. Changesin cytoplasmic and vacuolar $\mathrm{pH}$ in harvested lettuce tissue as influenced by $\mathrm{CO}_{2}$. J. Amer. Soc. $\mathrm{H}$ ort. Sci. 111:73-77.

Watkins, C.B., K. J. Silsby, and M.C. Goffinet. 1997. Controlled atmosphere and antioxidant effects on external $\mathrm{CO}_{2}$ injury of 'E mpire' apples. $\mathrm{H}$ ortScience 32:1242-1246.

Watkins, C.B., J.E., M anzano-M éndez, J.F. N ock, J. Zhang, and K.E. M aloney. 1999. Cultivar variation in response of strawberry fruit to high carbon dioxide treatments. J. Sci. Food Agr. 79:886-890.

Wilkinson, B.G. and J.C. Fidler. 1973. Injuries caused by incorrect concentrations of carbon dioxideand/ or oxygen, p. 81-87. In: J.C. Fidler, B.G. Wilkinson, K.L. Edney, and R.O. Sharples (eds.). The biology of apple and pear storage. Res. Rev. 3, Cmwlth. Bur. Hort. Plantation Crops, E. M alling, England.

Wright, K.P. and A.A. Kader. 1997. Effect of slicing and controlled-atmospherestorage on the ascorbate content and quality of strawberries and persimmons. Postharvest Biol. Technol. 10:3948.

Yang, Y., H . M urayama, and T. Fukushima.1998. Activation of glyoxylate enzymes in cucumber fruitsexposed to $\mathrm{CO}_{2}$. Plant Cell Physiol. 39:533539. 